\title{
Binary dietary responses of northern gannets Sula bassana indicate changing food web and oceanographic conditions
}

\author{
W. A. Montevecchi* \\ Cognitive and Behavioural Ecology Program, Memorial University, St. John's, Newfoundland A1B 3X9, Canada
}

\begin{abstract}
Interactions between seabirds and their prey are shaped largely by the dynamics of the marine ecosystems in which they are embedded. Physical oceanographic processes can drive the distributions of ectothermic and planktonic prey and hence their availability to marine birds. Owing to the complex nature of these processes and interactions, the signal-to-noise ratios of avian indicators of prey conditions are variable, often low and further degraded (buffered) by seabird behaviour and life-history features. Cairns (1987, Biol Oceanogr 5:261-271) detailed seabird responses operating over a range of temporal scales to variation in food supplies, and suggested that interval relationships might be developed between avian responses and environmental variation. While this may be possible in some instances, it appears unrealistic in most instances to expect interval relationships between seabird responses and prey conditions that are often nonlinearly related. The present paper focuses on binary data (e.g. breeding success versus failure) derived from seabirds that can provide robust information about major shifts in prey and oceanographic conditions and that are particularly informative when accumulated over decadal and large ocean scales. Inter-annual and decadal variations in specific and nominally categorized (warm- versus cold-water) prey landings of northern gannets Sula bassana at a large oceanic colony in the NW Atlantic reflect shifts in pelagic food webs induced by changes in regional sea surface temperature. Binary patterns emphasize decadal shifts in food webs and yield predictive indication of systemic change.
\end{abstract}

KEY WORDS: Binary patterns $\cdot$ Bio-indicators $\cdot$ Decadal scales $\cdot$ Seabirds $\cdot$ Ecosystem shift

\section{INTRODUCTION}

Considerable research has been directed at the exploitation of information from marine birds and mammals for purposes of assessing the changing states of prey bases and for detecting oceanographic and fisheries effects on top predators (e.g. Boyd et al. 2006, Piatt et al. 2007a, this issue). The physical dynamics of oceans exert considerable influence on interactions between seabird predators and their prey. Driven largely by ocean conditions, the distributions of ectothermic and planktonic prey determine their availability to avian predators (Scott et al. 2006). Owing to the stochastic nature of these processes and interactions, the signal-to-noise ratios of seabird indications of prey conditions are variable, frequently low and are degraded (buffered) by avian behaviour and lifehistory adaptations (e.g. flexible foraging tactics, deferred reproduction; Burger \& Piatt 1990, Montevecchi \& Berruti 1991, Daunt et al. 2006). Consequently, it is not simple to effectively derive insight from seabird data about changes in prey and ocean conditions. Yet biological signals complement and can even be more revealing than physical signals in detecting pervasive ocean perturbations, such as regime or ecosystem shifts (McFarlane et al. 2000, Hare \& Mantua 2000).

In a seminal paper on bio-indicators, Cairns (1987) proposed patterns of seabird responses operating over a range of temporal (and hence spatial) scales to changes in their prey base. The responses considered 
ranged from population through to behavioural levels and included adult survival, breeding success, chick growth, parental attendance and activity (foraging) budgets. Each response, with the exception of foraging budgets, was hypothesized to exhibit relatively sharp nonlinear changes to different levels of prey availability, which was considered on an ordinal scale between low and high. Cairns (1987, p 267) contended that '[a]t present seabird data can yield information on marine food supply on ordinal scales, but assigning food availability to interval or ratio scales must await rigorous testing of the relationships...'. Over the $20 \mathrm{yr}$ since Cairns' paper appeared, there have been numerous attempts to assess seabirds as indicators of prey conditions. The most recent of these sought to directly assess the predictions of Cairns' (1987) models, and found support for some of the predictions and not for others (Piatt et al. 2007b, this issue).

However, in most instances it is unrealistic to derive interval scaling between seabird responses and prey conditions that are often nonlinearly related. Yet this circumstance in no way precludes the derivation of information about marine ecosystems from seabird research. Associations of nominal patterns of seabird biology and prey and oceanographic conditions have proven highly informative in many instances (e.g. Schreiber \& Schreiber 1984). Binary relationships between avian predators, prey and oceanography gain considerable power and robustness as they are cumu- lated over time, space and species (Hatch 1996). For example, in an ocean-basin study of black-legged kittiwakes Rissa tridactyla, Hatch et al. (1993) demonstrated striking inter-annual patterns in the concordances and dis-concordances of reproductive success versus failure among colonies in the Bering Sea and Gulf of Alaska from 1978 through 1989 (Fig. 1). In 1978, colonies in the Bering Sea failed, while those in the Gulf of Alaska were productive. In 1984, this pattern reversed, whereas in 1988 all colonies throughout the study area were successful and in 1989 virtually all colonies failed. The information derived from these signals captured systemic patterns that occurred over scales that were larger than those of fishery activities and oceanographic research in the region.

The present paper builds on the potential of most studies of seabird ecology to detect binary changes in reproductive and behavioural parameters in response to environmental change. In this respect, I compare inter-annual and decadal associations in the species compositions of prey landings by northern gannets Sula bassana at a large oceanic colony with sea surface temperature (SST) patterns and anomalies in the NW Atlantic. Prey landings are assessed on a single-species basis and in nominal multi-species ecological classifications of prey from temperate/subtropical and from low Arctic Ocean regions, hereafter referred to as warm- and cold-water prey. Emphasis is directed at the cumulative information that can be derived for
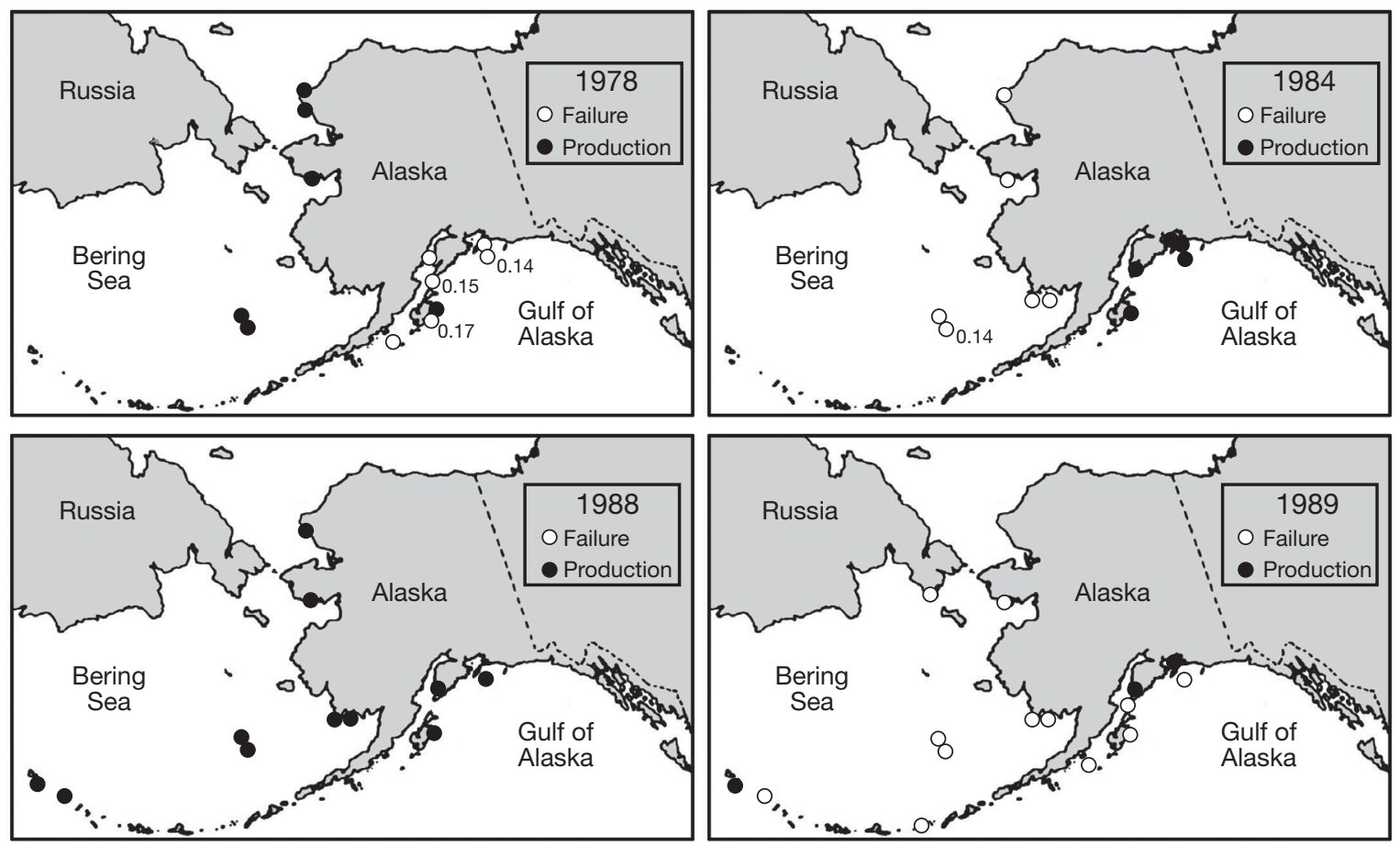

Fig. 1. Rissa tridactyla. Inter-annual ocean-basin patterns of breeding success (•) and failure (०) of black-legged kittiwakes at colonies in the North Pacific (after Hatch et al. 1993) 
these types of responses when combined over decades and longer and over large oceanographic scales to indicate shifts in food webs and ecosystem conditions.

\section{MATERIALS AND METHODS}

Study site. Research was conducted in Funk Island Ecological Reserve $\left(49^{\circ} 45^{\prime} \mathrm{N}, 53^{\circ} 11^{\prime} \mathrm{W}\right)$, a small $(800 \times$ $400 \mathrm{~m}$ ) flat granite rock in the northwest Atlantic (Montevecchi \& Tuck 1987), about $50 \mathrm{~km}$ off the northeast Newfoundland coast (Fig. 2), Canada. About 10000 pairs of northern gannets Sula bassana nest in the colony (Chardine 2000), which is the third largest and most oceanic of the 6 gannet colonies in North America.

Prey load sampling. Food samples were obtained by approaching roosting gannets that often regurgitated as they moved away from researchers (Montevecchi \& Myers 1995). Some samples were also obtained when gannets had GPS and other data loggers attached and removed and from discarded regurgitations and scraps in the colony. While there are likely differences between samples collected in roosts and in the colony, samples from all sources were comparable, so most

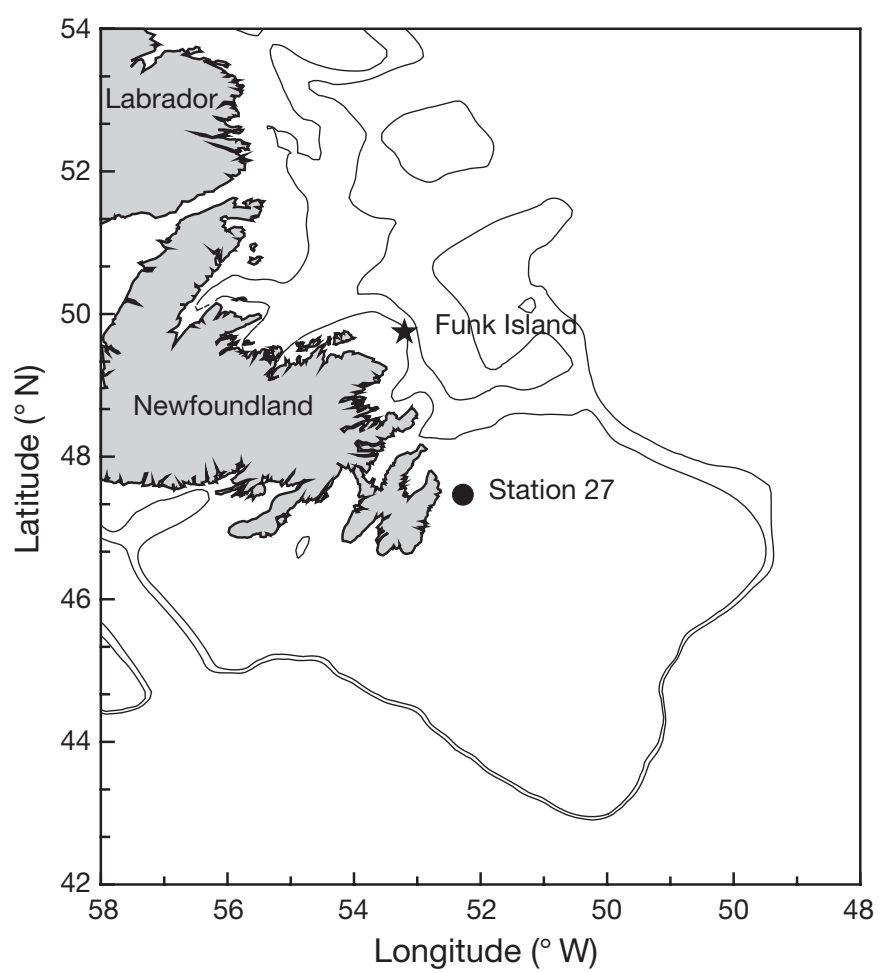

Fig. 2. Funk Island, off the NE coast of Newfoundland, Canada, is the site of the most oceanic and third largest of the 6 colonies of gannets in North America. Hydrographic Stn 27 is $20 \mathrm{~km}$ E of St. John's, Newfoundland, in the Avalon Channel of the Labrador Current regurgitations were collected at roosts well outside the colony to minimize disturbance to nesting areas. Regurgitated prey were identified to species, sex and condition (gravid, spent/immature) whenever possible. Prey landings are presented as percentages of the total estimated mass of prey landed during each year. A total of 8239 prey samples were obtained during late July and early to mid-August from 1977 to 2006, with the exception of 1981, when it was not possible to land on the island (Table 1).

Sea surface temperatures. SSTs (0 to $20 \mathrm{~m}$ ), corresponding with the maximum dive depths of northern gannets (Garthe et al. 2000), were obtained from Hydrographic Stn $27\left(48^{\circ} 32.8^{\prime} \mathrm{N}, 52^{\circ} 35.2^{\prime} \mathrm{W}\right)$ located $250 \mathrm{~km} \mathrm{~S}$ and downstream of Funk Island in the Labrador Current. The station has been checked regularly since its establishment in 1946. Measurements from Stn 27 provide robust ocean climate signals for the entire Newfoundland-Labrador Shelf (Petrie et al. 1988, Myers et al. 1990). Annual averages of SST during June, July and August were used.

Table 1. Sula bassana. Dates of collection and number of prey samples from gannets in the colony on Funk Island, 1977 to 2005

\begin{tabular}{|c|c|c|c|c|}
\hline Year & Date & $\begin{array}{c}\text { With } 1 \\
\text { species }\end{array}$ & $\begin{array}{l}\text { With }>1 \\
\text { species }\end{array}$ & Total \\
\hline 1977 & $12 \mathrm{Jul}$ & 105 & 0 & 105 \\
\hline 1978 & 11-20 Aug & 496 & 12 & 508 \\
\hline 1979 & 31 Jul-6 Aug & 162 & 4 & 166 \\
\hline 1980 & 1-9 Aug & 217 & 7 & 224 \\
\hline 1982 & 9-13 Aug & 191 & 25 & 216 \\
\hline 1983 & 5-13 Aug & 488 & 2 & 490 \\
\hline 1984 & 9-19 Aug & 225 & 8 & 233 \\
\hline 1985 & 4-10 Sep & 184 & 16 & 200 \\
\hline 1986 & 7-15 Aug & 493 & 22 & 515 \\
\hline 1987 & $22-26$ Aug & 144 & 8 & 152 \\
\hline 1988 & 12-20 Aug & 525 & 36 & 561 \\
\hline 1989 & 21-26 Aug & 380 & 27 & 407 \\
\hline 1990 & 18 Jul-11 Aug & 340 & 38 & 378 \\
\hline 1991 & 13 Jul-16 Aug & 411 & 21 & 432 \\
\hline 1992 & 5-10 Aug & 293 & 8 & 301 \\
\hline 1993 & 5-12 Aug & 258 & 18 & 276 \\
\hline 1994 & 11-14 Aug & 50 & 3 & 53 \\
\hline 1995 & 4-11 Aug & 279 & 2 & 281 \\
\hline 1996 & 5-8 Aug & 348 & 3 & 351 \\
\hline 1997 & 1-8 Aug & 244 & 2 & 246 \\
\hline 1998 & 3-17 Aug & 446 & 14 & 460 \\
\hline 1999 & 26 Jul-6 Aug & 98 & 1 & 99 \\
\hline 2000 & 6-12 Aug & 183 & 0 & 183 \\
\hline 2001 & 31 Jul-6 Aug & 202 & 12 & 214 \\
\hline 2002 & 8-12 Aug & 275 & 8 & 283 \\
\hline 2003 & 26 Jul-6 Aug & 391 & 2 & 393 \\
\hline 2004 & Jul 26-Aug 1 & 88 & 1 & 89 \\
\hline 2005 & 3-11 Aug & 200 & 0 & 200 \\
\hline 2006 & 6-14 Aug & 216 & 7 & 223 \\
\hline \multicolumn{2}{|c|}{ Totals 1977-2006 } & 7932 & 307 & 8239 \\
\hline
\end{tabular}




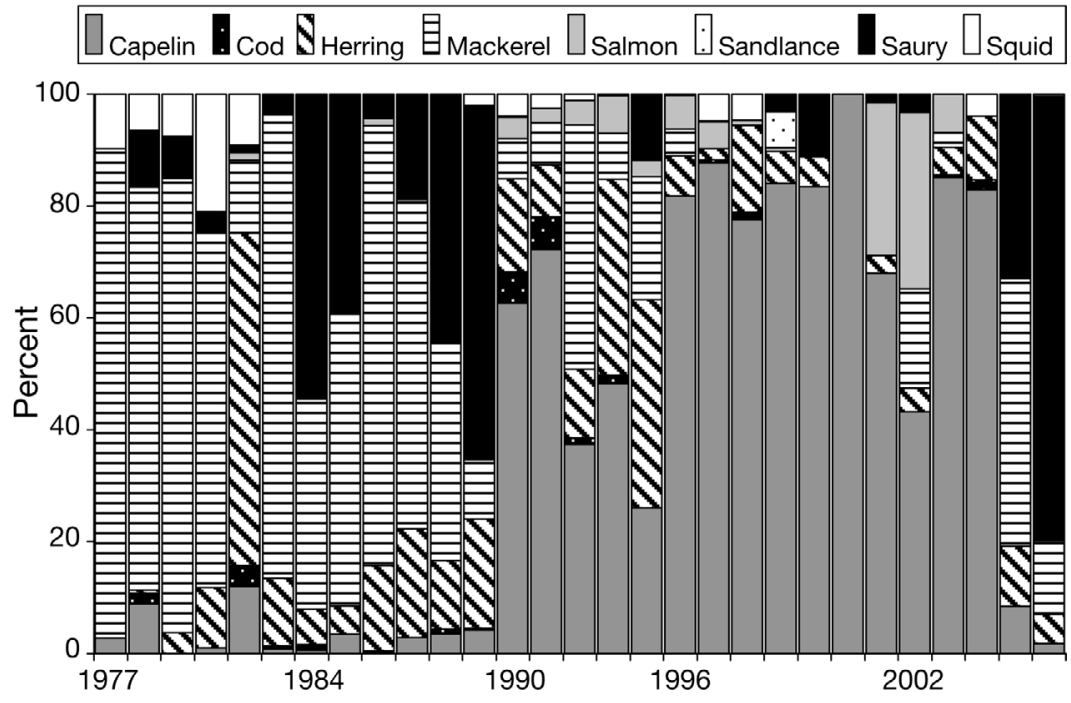

Fig. 3. Sula bassana. Estimated percentages of total mass of prey landed by northern gannets at the colony on Funk Island, 1977 to 2006

Data analyses. One-way ANOVAs and Tukey post hoc tests were used to compare decadal differences in the prey landings of gannets; chi-squared and binomial tests were used to assess decadal binary patterns in the gannets' landings of warm- and cold-water prey (Siegel 1957). Pearson correlations were run between individual prey species and between amalgamations of warm- and cold-water prey landings and SST. Level of significance is taken as $\mathrm{p}<0.05$.

\section{RESULTS}

\section{Inter-annual variation in prey landings}

As evident in their prey landings at Funk Island since 1977, gannets are generalist predators that exploit a diverse array of pelagic fish and squid with considerable inter-annual variation (chi-squared $=10$ 801.6, $\mathrm{df}=130$, $\mathrm{p}<0.0001$; Fig. 3). From 1977 to $1980,77 \pm 11 \%$ of the prey landed was Atlantic mackerel Scomber scombrus. In 1982, mackerel made up only $13 \%$ of the estimated prey landed and was replaced by Atlantic herring Clupea harengus, which represented $60 \%$ of the prey landed and which is second to mackerel in energy density among the gannets' prey spectrum (Montevecchi et al. 1984). In 1983, the relationship between the landings of these pelagic fishes was reversed, with mackerel comprising $83 \%$ of the landings and herring $12 \%$; this relationship of greater landings of mackerel compared to herring continued until 1989. From 1989 onward, mackerel was landed very irregularly by the gannets, with no landings from 1996 through 2001 and with contrasting large landings in 2005 and 2006. Her- ring were landed in large proportions in 1993 and 1994 (35 and 37\% of total mass, respectively; Fig. 3).

From 1977 to 1982, short-finned squid Illex illecebrosus made up from 7 to $21 \%$ of the prey landed, averaging $11 \pm 6 \%$ per yr. In contrast, squid were only landed in 7 of the years between 1983 and 2006 (1989 to 1992, 1996, $1997,2004)$, comprising $5 \%$ or usually less of the prey.

From 1977 to 1983, Atlantic saury Scomberesox saurus were either not landed (1977) or were a very minor component of the landings, ranging from 1 to $10 \%$. Then, in the mid- to late 1980s, saury was a major component of the gannets' prey every year except 1986 (percent of total mass of prey landed $=54 \%$ [1984], $39 \%$ [1985], $4 \%$ [1986], 19\% [1987], $44 \%$ [1988], $63 \%$ [1989]). From 1990 to 2004, no saury were landed in most years, in 5 of the years $<1$ to $3 \%$ were landed, and saury comprised 12 and $13 \%$ of the prey landed in 1994 and 1998, respectively. In 2005 and 2006, 33 and $80 \%$ of the prey landed by the gannets were Atlantic saury (Fig. 3). The mean percentages of saury landed during the $1970 \mathrm{~s} / 1980 \mathrm{~s}(20.85 \pm 22.95), 1990 \mathrm{~s}(2.65 \pm$ $4.78)$ and 2000s $(16.66 \pm 30.44)$, though differing by an order of magnitude, are not significantly different owing to the high inter-annual variability associated with the means $(F=2.15$, df $=2,26, \mathrm{p}=0.136)$.

Landings of Atlantic salmon Salmo salar during the 1970s/1980s, 1990s and 2000s differed significantly $(F=3.87$, df $=2,26, \mathrm{p}=0.034)$. From 1977 to 1989, Atlantic salmon was landed in minute amounts, ranging from 0 to $1.4 \%$ of the estimated total landings, averaging $0.31 \%$ of the prey landed per yr. Circumstances changed in 1990, and from 1990 to 1996 salmon comprised from 3 to $7 \%$ of gannets' annual prey landings. During the 1990s, Atlantic salmon averaged $3.4 \%$ of the total prey landed per yr. The largest harvests of salmon occurred in 2001 and 2002 (27 and $32 \%$ of the total mass of prey landed, respectively). Seven percent of the landings in 2003 were salmon, and none were landed thereafter (Fig. 4). Landings from 2000 to 2006 averaged $9.3 \%$ of the annual prey landings.

From 1977 to 1989, capelin Mallotus villosus, a small forage fish, comprised $<5 \%$ of the mass of gannets' prey landings in all years except in 1978 (9\%) and 1982 $(12 \%)$, when small amounts were also landed (Fig. 3). From 1989 until 2004, capelin was a common prey of gannets, ranging from 26 to $100 \%$ of prey landed each year. Significantly less capelin was landed by gannets 


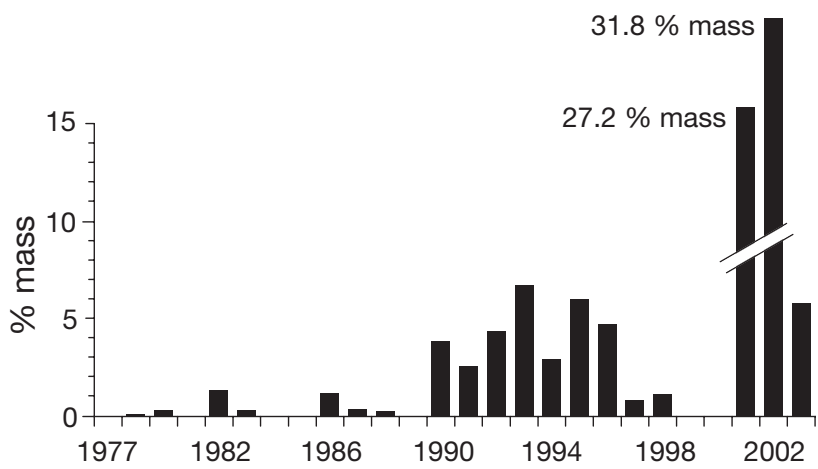

Fig. 4. Salmo salar. Estimated percentages of total mass of Atlantic salmon landed in the northern gannet colony on Funk Island from 1977 to 2006

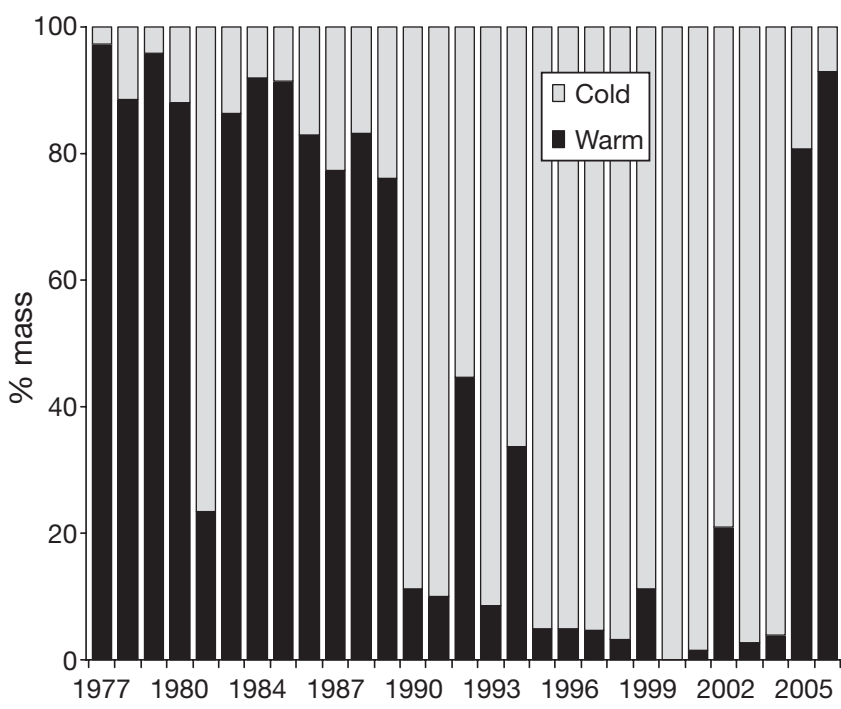

Fig. 5. Sula bassana. Warm-water prey (mackerel, squid, saury) from boreal and subtropical ocean regions and low arctic cold-water prey (herring, capelin, salmon, sandlance, cod), as percentages of total mass of prey landed by northern gannets in the colony on Funk Island, 1977 to 2006 in the $1970 \mathrm{~s} / 1980 \mathrm{~s}$ than in the 1990s and 2000s $(F=$ 23.68, df $=2,26, \mathrm{p}<0.001$ and Tukey post hoc test).

Small amounts of cod Gadus morhoa (discards) and sandlance Ammodytes sp. were also landed in 1 or 2 of the years.

\section{Decadal variation in prey landings}

When these highly variable prey landings of the gannets are collapsed into the binary categories of warm-water migratory prey (mackerel, squid, saury) from temperate and cool subtropical ocean regions and cold-water low arctic prey (herring, capelin, salmon, sandlance, cod), striking decadal patterns emerge (Fig. 5). Migratory warm-water species comprised most of the gannets' prey landings in the late 1970s and throughout the 1980s (binomial test of equal proportions of warm- and cold-water prey, $p=0.003$ ). In a marked reversal of this pattern, from 1990 through 2004 cold-water prey comprised almost all of the gannets' prey landings (binomial test of equal proportions of warm- and cold-water prey, $\mathrm{p}<0.001)$. A comparison of the landings of warm-water migratory prey landed before and after the 1991 cold-water perturbation (Fig. 6) proves to be highly significant $(F=43.57$, $\mathrm{df}=1,27, \mathrm{p}<0.001$ ). In 2005 and 2006, for the first time since 1989, migratory warm-water pelagic fishes comprised 81 and $93 \%$, respectively, of the estimated prey landed by gannets.

\section{Annual and decadal associations between prey landings and SST}

Following the lowest SST on record in 1991, values returned to positive thermal anomalies by the mid- to late 1990s (Fig. 6). Still, warm-water migratory prey did not regain their dominance in the gannets' prey landings until 2005, lagging about a decade after the reoccurrence of positive SST signals (Fig. 4). Sixteen years passed (from 1989 to 2005) before warm-water prey again dominated landings. 2005 was a warm-water year in the region (but not the warmest in recent years). There were no significant associations between the annual landings of any prey or combined landings of warm- or cold-water prey and average annual SST from 1977 to 2006. The prevalence of migratory warm-water pelagic species in the gannets' prey landings continued in 2006.
Fig. 6. June to July annual (gray) and 5 yr running average (black) of sea surface temperature anomalies obtained from Hydrographic Stn 27. Arrow indicates the most extreme negative anomaly on record that acted as a physical forcer in 1991 to induce a shift in the pelagic food web (DFO 2005) 


\section{DISCUSSION}

A highly flexible foraging strategy directed at a wide breadth of pelagic prey is a striking feature of the northern gannets' Sula bassana feeding ecology (e.g. Garthe et al. 2007). The generalist pattern of their changing dietary diversity is evident in their prey landings on Funk Island from 1977 through 2006. Inter-annual variation in the gannets' landings of mackerel and squid exhibited significant correlations with commercial landings and independent research indices of these species over multiple spatial and temporal scales beyond the gannets' foraging range around the colony (Montevecchi \& Myers 1995). These associations are driven by prey availability, largely by negative events when birds and humans catch little or none of a particular pelagic species.

\section{Physical forcing and lagging biological responses}

The 1991 cold-water perturbation in the NW Atlantic - a centennially significant event (Drinkwater 1996) - acted as a physical forcer that influenced and inhibited warm-water pelagic species such as mackerel, saury and squid from migrating into the region (Montevecchi \& Myers 1995). This cold-water incursion induced an extensive regime-type shift in the pelagic food web (Montevecchi \& Myers 1996). By the mid1990s, SSTs had returned to pre-perturbation levels, yet a return to prior warm-water prey landings by both birds and commercial fishers lagged by about another 10 yr (see also Davoren \& Montevecchi 2003). It is this type of on/off response that is responsible for the lack of inter-annual associations (correlations) between the prey landings of birds and average annual SSTs. These decadal patterns and their coincidence with oceanographic perturbation are clarified when the variation in inter-annual prey landings are lumped into the binary categories of warm- and cold-water prey.

\section{Binary responses and systemic shifts}

Binary classification, amalgamation and analysis can provide robust signals from apex marine predators (see Hatch 1996 for analyses of binary patterns). In 2005 , the prominence of migratory warm-water mackerel and saury in the gannets' landings returned for the first time in 16 yr. This avian signal of warm-water prey also coincided with the largest mackerel fishery landings in the Newfoundland region since 1989 (NAFO Division 3K and 3L reports; M. Koen-Alonso pers. comm).
The changes in prey landings by the gannets signalled a shift in the pelagic food web driven by oceanographic changes, leading to greater representation of migratory warm-water pelagic species in regional seasonal assemblages and food webs. These signals from seabirds can also be used to anticipate predator-prey and wider food web and oceanographic patterns. As predicted (Montevecchi 2005), ocean temperatures were warm and the mackerel fishery flourished in 2006. The prey landings of gannets in 2006 were again dominated by migratory warm-water prey from temperate and subtropical ocean regions, and ocean temperatures in the NW Atlantic were among the warmest on record (E. Colbourne pers. comm.). In the NW Atlantic in 2006, auks laid their eggs about 2 wk earlier than in previous years, spawning capelin and humpback whales Megaptera novaeanglia moved inshore early, lumpfish Cyclopterus lumpus were eggladen in May, well before their usual time during summer and large squid were abundant in inshore waters (W.A.M., D. Fifield, A. Hedd, J. Lavers, T. and K. Power pers. obs.). So at least during 2005 and 2006, a shift back to warm-water ecosystem conditions was evident. Continuation of this warm-water condition occurred in 2007 and is expected to continue further.

\section{Seabird indicators}

Seabird studies of biophysical environmental conditions have proven highly informative in other contexts. For instance, broad-scale biological shifts are driven at times by radical state changes (abundance versus scarcity) exhibited by focal forage species that fuel large vertebrate food webs (Chavez et al. 2003). Seabird studies are particularly useful in documenting condition changes in these forage species (e.g. Österblom et al. 2001, Davoren \& Montevecchi 2003, Miller \& Sydeman 2004, Wanless et al. 2004, 2005) that often reflect food resource states. Importantly, seabirds also target prey that are not commercially exploited (and hence excluded from most fishery research programs) or are not accessible to standard survey methods (Barrett et al. 1990, Montevecchi 1993). Recent studies use data-logging devices to interrogate free-ranging seabirds and mammals about environmental information (Wilson et al. 2002, Daunt et al. 2003, 2006, Garthe et al. 2007). When carried out in conjunction with vessel surveys of prey densities and distributions, these studies hold the further potential of detailing the behaviour and decisionmaking of individual foragers (Garthe et al. 2000, Ollason et al. 2006, Staniland et al. 2006) and directly assessing functional responses, the mechanisms of higher level population patterns. 
Acknowledgements. I thank C. Burke for superb work accessing and manipulating data sets and preparing figures. Thanks to D. Fifield, A. Hedd, J. Lavers and T. and K. Power for observations, and to $\mathrm{M}$. Koen-Alonso for accessing catch statistics for mackerel and short-finned squid. I thank D. Cairns and 4 anonymous reviewers for constructive suggestions on the paper. Many thanks to all those who have joined me on that marvellously terrible place, Funk Island, to engage in seabird studies and to collect gannet 'yuks' over the decades-C. Burke, D. Cairns, G. Davoren, L. Dominguez, E, L. and T. Easton, D. Fifield, V. Friesen, S. Garthe, J. Heath, A. Hedd, I. Kirkham, N. Montevecchi, J. Porter, J. Russell, I. Stenhouse and S. Windsor. I am grateful to J. Piatt and B. Sydeman for the opportunity to participate in Pacific Seabird Group 'Seabirds as Indicators Symposium'. Long-term research support from Memorial University of Newfoundland, the Natural Sciences and Engineering Research Council of Canada (NSERC) and Fisheries and Oceans Canada is gratefully acknowledged.

\section{LITERATURE CITED}

Barrett RT, Røv N, Loen J, Montevecchi WA (1990) Diets of shags Phalacrocorax aristotelis and cormorants $P$. carbo in Norway and implications for gadoid stock recruitment. Mar Ecol Prog Ser 66:205-218

Boyd IL, Wanless S, Camphuysen CJ (eds) (2006) Top predators in marine ecosystems: their role in monitoring and management. Cambridge University Press, Cambridge

Burger AE, Piatt JF (1990) Flexible time budgets in breeding common murres: buffers against variable prey abundance. Stud Avian Biol 14:71-83

Cairns DK (1987) Seabirds as indicators of marine food supplies. Biol Oceanogr 5:261-271

Chardine JW (2000) Census of northern gannet colonies in the Atlantic Region in 1999. Can Wildl Serv Tech Rep Ser 361:1-16

Chavez FP, Ryan J, LLuch-Cota SE, Niquen CM (2003) From anchovies to sardines and back: multidecadal change in the Pacific Ocean. Science 299:217-221

Daunt F, Peters G, Scott B, Grémillet D, Wanless S (2003) Rapid-response recorders reveal interplay between marine physics and seabird behaviour. Mar Ecol Prog Ser 255: 283-288

Daunt F, Wanless S, Peters G, Benvenuti S, Sharples J, Grémillet D, Scott B (2006) Impacts of oceanography on the foraging dynamics of seabirds in the North Sea. In: Boyd IL, Wanless S, Camphuysen CJ (eds) Top predators in marine ecosystems: their role in monitoring and management. Cambridge University Press, Cambridge, p 177-190

Davoren GK, Montevecchi WA (2003) Signals from seabirds indicate changing fish stocks. Mar Ecol Prog Ser 258: 253-261

DFO (Department of Fisheries and Oceans Canada) (2005) 2004 state of the ocean: physical oceanographic conditions in the Newfoundland and Labrador Region. DFO Can Sci Advis Sec Sci Advis Rep 2005/018, available at: www.dfo-mpo.gc.ca/csas/Csas/status/2005/SAR-AS2005_ 018_E.pdf

Drinkwater KF (1996) Atmospheric and oceanographic variability in the northwest Atlantic during the 1980s and early 1990s. J Northw Atl Fish Sci 18:77-97

Garthe S, Benvenuti S, Montevecchi WA (2000) Pursuitplunging by gannets (Morus bassana) feeding on capelin (Mallotus villosus). Proc R Soc Lond B 267:1717-1722
Garthe S, Montevecchi WA, Chapdelaine G, Rail JF, Hedd A (2007) Contrasting foraging tactics of seabirds breeding in different oceanographic domains. Mar Biol 151:687-694

Hare S, Mantua N (2000) Empirical evidence of North Pacific regime shifts in 1977 and 1989. Prog Oceanogr 47:103-145

Hatch SA (1996) Concordance of seabird population parameters: analytical methods and interpretation. In: Montevecchi WA (ed) Studies of high-latitude seabirds. 4. Trophic relationships and energetics of endotherms in cold water. Can Wildl Serv Occas Pap 21, p 37-48

Hatch SA, Byrd GV, Irons DB, Hunt GL Jr (1993) Status and ecology of kittiwakes (Rissa tridactyla and $R$. brevirostris) in the North Pacific. In: Vermeer K, Briggs KT, Morgan $\mathrm{KH}$, Siegel-Causey D (eds) The status, ecology, and conservation of marine birds in the North Pacific. Can Wildl Serv Spec Publ, Ottawa, p 140-153

MacFarlane GA, King JR, Beamish RJ (2000) Have there been recent changes in climate? Ask the fish. Prog Oceanogr 47:147-169

Miller AK, Sydeman WJ (2004) Rockfish response to low-frequency ocean climate change as revealed by the diet of a marine bird over multiple time scales. Mar Ecol Prog Ser 281:207-216

Montevecchi WA (1993) Birds as indicators of change in marine prey stocks. In: Furness RW, Greenwood JJD (eds) Birds as monitors of environmental change. Chapman \& Hall, London, p 217-266

Montevecchi WA (2006) Simple is useful: binary responses of seabirds to changing prey and oceanographic conditions. Proc Pacific Seabird Group 33rd Annual Meeting, Girdwood, Alaska, Abstract available at: www. pacificseabirdgroup.org/downloads/Girdwood.pdf

Montevecchi WA, Berruti A (1991) Avian indication of pelagic fisheries and trophic changes in the southeast and northwest Atlantic. Acta 20th Congr Int Ornithol 4:2246-2256

Montevecchi WA, Myers RA (1995) Prey harvests of seabirds reflect pelagic fish and squid abundance on multiple spatial and temporal scales. Mar Ecol Prog Ser 117:1-9

Montevecchi WA, Myers RA (1996) Dietary changes of seabirds reflect shifts in pelagic food webs. Sarsia 80:313-322

Montevecchi WA, Tuck LM (1987) Newfoundland birds: exploitation, study, conservation. Nuttall Ornithological Club, Cambridge, MA

Montevecchi WA, Ricklefs RE, Kirkham IR, Gabaldon D (1984) Growth energetics of nestling northern gannets, Sula bassana. Auk 101:334-341

Myers RA, Akenhead SA, Drinkwater K (1990) The influence of the Hudson Bay runoff and ice melt on the salinity of the inner Newfoundland Shelf. Atmospere-Ocean 28: 241-256

Ollason JG, Yearsley JM, Liu K, Ren R (2006) Modelling the behaviour of individuals and groups of animals foraging in heterogeneous environments. In: Boyd IL, Wanless S, Camphuysen CJ (eds) Top predators in marine ecosystems: their role in monitoring and management. Cambridge University Press, Cambridge, p 294-309

Österblom H, Bignert A, Fransson T, Olsson O (2001) A decrease in fledging body mass in common guillemot Uria aalge chicks in the Baltic Sea. Mar Ecol Prog Ser 224: 305-309

Petrie B, Akenhead SA, Lazier S, Loder J (1988) The cold intermediate layer on the Labrador and Northeast Newfoundland Shelves, 1978-86. North Atlantic Fish Org Sci Council Stud 12:57-69

Piatt JF, Sydemann WJ, Wiese F (2007a) Introduction: a modern role for seabirds as indicators. Mar Ecol Prog Ser 352: 199-204 
Piatt JF, Harding AMA, Shultz M, Speckmann SG, Van Pelt TI, Drew GS, Kettle AB (2007b) Seabirds as indicators of marine food supplies: Cairns revisited. Mar Ecol Prog Ser 352:221-234

Schreiber RW, Schreiber EA (1984) Central Pacific seabirds and the El Niño southern oscillation: 1982 to 1983 retrospectives. Science 225:713-716

Scott BE, Sharples J, Wanless S, Ross ON, Frederiksen M, Daunt F (2006) The use of biologically meaningful climate and fisheries on seabird breeding success. In: Boyd IL, Wanless S, Camphuysen CJ (eds) Top predators in marine ecosystems: their role in monitoring and management. Cambridge University Press, Cambridge, p 46-62

Siegel S (1957) Nonparametric statistics. McGraw-Hill, New York

Staniland IJ, Trathan P, Martin AR (2006) Consequences of

Editorial responsibility: Howard Browman (Associate Editorin-Chief), Storebø, Norway prey distributions for the foraging behaviour of top predators. In: Boyd IL, Wanless S, Camphuysen CJ (eds) Top predators in marine ecosystems: their role in monitoring and management. Cambridge University Press, Cambridge, $\mathrm{p} 131-142$

Wanless S, Wright PJ, Harris MP, Elston DA (2004) Evidence for a decrease in size of lesser sandeels Ammodytes marinus in a North Sea aggregation over a 30-yr period. Mar Ecol Prog Ser 279:237-246

Wanless S, Harris MP, Redman P, Speakman JR (2005) Low energy values of fish as a probable cause of a major seabird breeding failure in the North Sea. Mar Ecol Prog Ser 294:1-8

Wilson RP, Grémillet D, Syder J, Kierspel MAM and 7 others (2002) Remote-sensing systems and seabirds: their use, abuse and potential for measuring marine environmental variables. Mar Ecol Prog Ser 228: 241-261

Submitted: September 28, 2006; Accepted: July 27, 2007 Proofs received from author(s): October 28, 2007 